American Journal of Economics and Business Administration 4 (1): 40-46, 2012

ISSN 1945-5488

(C) 2012 Science Publications

\title{
Trans Pacific Strategic Economic Partnership With Japan, South Korea and China Integrate: General Equilibrium Approach
}

\author{
${ }^{1}$ Todsadee Areerat, ${ }^{2}$ Hiroshi Kameyama, ${ }^{3}$ Shoichi Ito and ${ }^{2}$ Koh-en Yamauchi \\ ${ }^{1}$ The United Graduate School of Agricultural Science, \\ Ehime University, Matsuyama, Ehime, Japan \\ ${ }^{2}$ Department of Applied Bioresource, \\ Faculty of Agriculture, Kagawa University, Kagawa, Japan \\ ${ }^{3}$ Department of Agricultural and Resource Economics, \\ Faculty ofAgriculture, Kyushu University, Fukuoka, Japan
}

\begin{abstract}
Problem statement: The Trans-Pacific Strategic Economic Partnership Agreement (TPP) is a high standard and broad based Free Trade Agreement that aims to integrate the economies of the Asia-Pacific region. Recently, the US is pressing Japan to join the group. Japan is considering joining the TPP because of the dual considerations of its own economy and the political situation in East Asia. While, South Korea has yet to agree to join the TPP over concerns that their agriculture will be seriously affected. In addition, Japan and the US are employing both military and economic strategies to isolate China. However, China has contacted those already participating in TPP negotiations and shares some common views with Japan and South Korea on agricultural issues. Therefore, in this study, we attempt to assess the possibility of reaching full trade liberalization or trade creation through the TPP with the addition of new member countries including Japan, Korea and China. Approach: A Computable General Equilibrium (CGE) or Global Trade Analysis Project (GTAP) model is used to evaluate the economic effects of a TPP agreement among TPP countries with trade creation. In this study, seven cases were created to distinguish the welfare and trade effects of policy changes. Results: We found that the new member countries among TPP countries with East Asia countries including Japan, South Korea and China would benefit from the FTA among member countries. They gain much more from the real GDP and welfare than the TPP agreement, particularly Vietnam and Korea. This is particularly a fact for trade in the meat product sectors between TPP with Japan, Korea and China, which most of them gain benefit. Conclusion: Therefore, the TPP would benefit both economies and welfare with the eliminate tariff rate.
\end{abstract}

Key words: Trans-pacific strategic economic partnership, Free Trade Agreement (FTA), aggregation, Computable General Equilibrium (CGE), GTAP

\section{INTRODUCTION}

In the past decades, many developed and developing countries have concluded regional and multilateral FTAs to enchance their trade and boost ther economic growth. The Trans-Pacific Strategic Economic Partnership Agreement (TPP) is a trade agreement, which is currently under negotiation. The TPP is based on an existing agreement between Brunei Darussalam, Chile, New Zealand and Singapore-better known as "the P4 Agreement" -that was signed in 2005 (Fergusson and Vaughn, 2011). The objective of the original agreement was to eliminate $90 \%$ of all tariffs between member countries by January 1, 2006 and reduce all trade tariffs to zero by the year 2015 . It is comprehensive agreement covering all main pillars of a free trade agreement, including in good, rule of origin trade remedies sanitary and phytosanitary measure, technical barriers to trade, trade in service, intellectual property, government and competition policy (USDMNZ, 2012; Kuriyama, 2011). The goal of the four original TPP members was not to form a union based on economic synergies, but rather to create a model agreement that could be expanded to include additional members from both sides of the Pacific (Herreros, 2011). In other words, the TPP is a

Corresponding Author: Hiroshi Kameyama, Department of Applied Bioresource, Faculty of Agriculture, Kagawa University, Miki-Cho, Kagawa-Ken, 761-0795, Japan 


\section{Am. J. of Economics and Business Administration 4 (1): 40-46, 2012}

multilateral Free Trade Agreement (FTA) that aims to further liberalize the economies of the Asia-Pacific region. Australia, Malaysia, Peru, the US and Vietnam are currently negotiating to join the TPP (Fergusson and Vaughn, 2011).

Moreover, Japan is interested in joining the TPP due to concerns over its own economic interests and the political situation in East Asia. Japan is also is making efforts to join the TPP to alleviate concerns about the negative effects the TPP could have on its automotive and electronics industries.

Japanese Prime Minister, Naoto Kan, clarified that he would bring Japan into the TPP negotiating process to boost the growth of Japanese economy. On November 9, 2010, the Japanese cabinet approved the "basic principles of economic cooperation." Its core issue is to begin TPP negotiation with the US, New Zealand and other countries. Meanwhile, with regards to the TPP's negative impact on Japanese agriculture (Bin, 2011).

In the mid-to long-term, Japan participation, TPP would boost growth and sustain recovery by ushering in economic reforms in some key areas that will make the economy more dy namic and competitive and a more attractive place to invest and operate (USJBC, 2011).

The Japanese government will spend up the completion of basic agricultural reforms and improve domestic (agricultural) environment. However, Japan and the U.S. are employing both military and economic strategies to isolate China. It has become the shared political goal of Japan and the US to counterbalance China's important position in East Asia and in AsiaPacific. However, China has contacted those already participating in TPP negotiation and shares some common views with Japan and South Korea on agricultural issues. Meanwhile, as an important part of China's foreign trade strategy, the Chinese government would promote more actively any form of FTA negotiations .

South Korea already has bilateral trade agreements with other TPP countries, South Korea-US and ASEAN+3 (Lee and Sumner, 2011); thus, making any future multilateral TPP negotiations relatively easier and less complicated WTO International Trade, 2011 (Broadbent el al., 2012). Therefore, South Korea has no reason stay out of the zone. However, they are waiting to join the TPP because some industries, specifically agriculture, will be seriously affected. After observing for more than a year, for the time being, South Korea has basically determined that it will not join the TPP talks because of agriculture development.

Akira (2004), point out that Japan, South Korea, China Taiwan and ASEAN countries participate in TPP agreement, real GDP will increase but its growth rate was less than $1 \%$ for both benefit production and export of industrial products. However, ASEAN countries are not members in the TPP, their real GDP was negatively affected. However, if ASEAN countries participate in the TPP free trade bloc, their real GDP increased in all member countries, specially ASEAN, South Korea, Japan and China white non-member, EU and Other determine in real GDP.

It is clear that if South Korea, Japan and, China were to join the TPP free trade bloc, it would boost the ASEAN countries' economies.

Therefore, in this study we attempt to assess the possibility of reaching full trade liberalization or trade creation through the TPP with the addition of new member countries including Japan, South Korea and China. The objective of this study is to study the impact of trade liberalization before and after China and South Korea join the TPP.

\section{MATERIALS AND METHODS}

To provide quantitative assessment on the TPP's effect on welfare and real GDP, the following Computable General Equilibrium (CGE) models have been adopted (APEC, 2009; Innwon el al., 2010). Computable General Equilibrium (CGE) models are frequently used for economic policy analysis and, since the Uruguay Round, have formed the basis for policy advice and recommendations to developing countries on the potential impact of multilateral trade liberalization on their economies (DeRose, 1995; APC, 2009). CGE models of trade allow researchers to provide a quantitative estimate of the potential economic consequences of different trade liberalization scenarios. This includes the impact on welfare, trade flows, prices, consumption and production. Because CGE models adopt a multi-sector and multi-region general equilibrium framework, they are also able to capture interactions of different sectors and markets in a given economy and at the international level (Hakim and Osakwe, 2006).

In addition, we have used a Global Trade Analysis Project (GTAP) model that has been extensively used in studies to examine a wide variety of trade policy issues. GTAP was intially developed in 1992 at Purdue University, USA. The GTAP model is multi-regional, applied general equilibrium model (Hertel, 1999; Dimarana and McDougall, 2002). Moreover, the model provides a framework for assessing the effects of policy and structural changes on resource allocation by clarifying "who gains and who loese" (Todsadee el al., 2012). 
Am. J. of Economics and Business Administration 4 (1): 40-46, 2012

Table 1: Separated the individual country/region

\begin{tabular}{|c|c|c|c|c|c|c|c|c|}
\hline Countries & TPP & $\mathrm{TPP}+\mathrm{J}$ & TPP+K & $\mathrm{TPP}+\mathrm{C}$ & $\mathrm{TPP}+\mathrm{J}+\mathrm{K}$ & $\mathrm{TPP}+\mathrm{J}+\mathrm{C}$ & $\mathrm{TPP}+\mathrm{K}+\mathrm{C}$ & $\mathrm{TPP}+\mathrm{J}+\mathrm{K}+\mathrm{C}$ \\
\hline Australia & $\sqrt{ }$ & $\sqrt{ }$ & $\sqrt{ }$ & $\sqrt{ }$ & $\sqrt{ }$ & $\sqrt{ }$ & $\sqrt{ }$ & $\sqrt{ }$ \\
\hline Chile & $\sqrt{ }$ & $\sqrt{ }$ & $\sqrt{ }$ & $\sqrt{ }$ & $\sqrt{ }$ & $\sqrt{ }$ & $\sqrt{ }$ & $\sqrt{ }$ \\
\hline New Zealand & $\sqrt{ }$ & $\sqrt{ }$ & $\sqrt{ }$ & $\sqrt{ }$ & $\sqrt{ }$ & $\sqrt{ }$ & $\sqrt{ }$ & $\sqrt{ }$ \\
\hline Peru & $\sqrt{ }$ & $\sqrt{ }$ & $\sqrt{ }$ & $\sqrt{ }$ & $\sqrt{ }$ & $\sqrt{ }$ & $\sqrt{ }$ & $\sqrt{ }$ \\
\hline Singapore & $\sqrt{ }$ & $\sqrt{ }$ & $\sqrt{ }$ & $\sqrt{ }$ & $\sqrt{ }$ & $\sqrt{ }$ & $\sqrt{ }$ & $\sqrt{ }$ \\
\hline USA & $\sqrt{ }$ & $\sqrt{ }$ & $\sqrt{ }$ & $\sqrt{ }$ & $\sqrt{ }$ & $\sqrt{ }$ & $\sqrt{ }$ & $\sqrt{ }$ \\
\hline Vietnam & $\sqrt{ }$ & $\sqrt{ }$ & $\sqrt{ }$ & $\sqrt{ }$ & $\sqrt{ }$ & $\sqrt{ }$ & $\sqrt{ }$ & $\sqrt{ }$ \\
\hline Japan & - & $\sqrt{ }$ & - & - & $\sqrt{ }$ & $\sqrt{ }$ & - & $\sqrt{ }$ \\
\hline China & - & - & $\sqrt{ }$ & $\sqrt{ }$ & - & $\sqrt{ }$ & $\sqrt{ }$ & $\sqrt{ }$ \\
\hline South Korea & - & - & - & - & $\sqrt{ }$ & - & $\sqrt{ }$ & $\sqrt{ }$ \\
\hline
\end{tabular}

Source: Author's calculation

GTAP version 7 is the source of the data for simulation. It covers 113 regions, 57 commodities or sectors and five primary sectors. The database corresponds to the world economy based on a 2004 benchmark (Narayanan and Walmsley, 2008; Person and Horridge, 2003). For this model, the original GTAP dataset was aggregated down to 17 regions and 14 sectors (17 regions: Australia, Chile, New Zealand, Peru, Singapore, US, Vietnam, Japan, China, South Korea, Canada, Mexico and Malaysia, ASEAN, Latin America, EU and Rest of the world; 15 sectors: Rice, Wheat, Grains, Vegetable and fruit, livestock, Meat product, Fishing, Process food, Natural resource, Textiles and apparel, Light Manufacturing, Heavy Manufacturing, Utilities and Construction, Trade, transport, communication and other service). With the above aggregation of the regions and sectors, the paper examines the effects of the following (hypothetical) TPP.

The individual countries/regions have been separated to the maximum extent possible to distinguish the welfare and trade effects of policy changes by country/region and by sector based on similarities in factor shares and characteristics. Among the seven scenarios, a comparison of the results of the following three scenarios would be of particular interest: TPP among present members plus China $(\mathrm{TPP}+\mathrm{C})$; TPP among the present members plus Korea $(\mathrm{TPP}+\mathrm{K})$; and TPP among the present members plus Japan, China and Korea $(\mathrm{TPP}+\mathrm{J}+\mathrm{C}+\mathrm{K})($ Table 1$)$.

To analyze the effects of TPP on both the members and non-members in general as a reference value, it is assumed that all tariffs in all sectors would be eliminated.

To compare several types of East Asian TPP framework, our study basically focuses on TPP and $\mathrm{TPP}+\mathrm{J}+\mathrm{C}+\mathrm{K}$. However, global trade liberalization is also examined as a reference.

\section{RESULTS}

This results is reported the macroeconomic, sectoral and welfare effects of the seven TPP scenarios. The results provide evidence as to whether or not there is trade creation and/or trade diversion following the formation of the TPP and the estimated impact on trade flows with Japan, China and Korea when they join the TPP.

In Table 2, real GDP is the first measurement. Among the seven scenarios, the $\mathrm{TPP}+\mathrm{J}+\mathrm{C}+\mathrm{K}$ scenario shows the most benefit regarding the effects through trade liberalization at 0 tariff rates to all individual member countries except Peru. In this scenario, the changes in real GDP are 2.4\% for Vietnam, 1.00 for Korea, 0.30 for China, 0.20 for Japan, 0.10 for both New Zealand and Australia, 0.03 for both Singapore and Chile and 0.003 for the US. The results confirm that the $\mathrm{TPP}+\mathrm{J}+\mathrm{C}+\mathrm{K}$ scenario creates the largest gains for the member economies. However, the projection suggests that the TPP would have a negative for all non-member economies except for Mexico in all cases and Malaysia in case of TPP. This result supports arguments that the TPP is beneficial to member countries but detrimental to nonmember countries. In general, non-members would be at a disadvantage as a result of trade diversion. In addition, comparing the change of real GDP and trade creation with Japan, Korea and, China joining the TPP shows that the value of real GDP and trade creation increases more than with only the present members including Australia, Chile, New Zealand, Peru, Singapore, the US and Vietnam. However, Peru shows negative real GDP in all cases of trade liberalization and trade creation, which means that Peru will not benefit from the TPP agreement.

The second measurement, also shown in Table 3, is the EV, or the net welfare gains from the TPP. The EV measures the amount of income that would have to be given or taken away from an economy before trade liberalization leaves the economy as well off as it would be before the policy had been changed (Dixit, 1975; Hanslow, 2000). 
Am. J. of Economics and Business Administration 4 (1): 40-46, 2012

Table 2: Real GDP and Equivalent Variation (EV), (Unit: percent change and USD million)

\begin{tabular}{|c|c|c|c|c|c|c|c|c|}
\hline & \multicolumn{8}{|c|}{ Percent change in real GDP } \\
\hline & TPP & $\mathrm{TPP}+\mathrm{J}$ & $\mathrm{TPP}+\mathrm{K}$ & $\mathrm{TPP}+\mathrm{C}$ & $\mathrm{TPP}+\mathrm{J}+\mathrm{K}$ & $\mathrm{TPP}+\mathrm{J}+\mathrm{C}$ & TPPP+K+C Regions & $\mathrm{TPP}+\mathrm{J}+\mathrm{K}+\mathrm{C}$ \\
\hline Australia & 0.001 & 0.030 & 0.010 & 0.05 & 0.08 & 0.05 & 0.06 & 0.100 \\
\hline New Zealand & 0.030 & 0.060 & 0.040 & 0.06 & 0.08 & 0.06 & 0.06 & 0.100 \\
\hline Singapore & 0.020 & 0.020 & 0.020 & 0.03 & 0.02 & 0.03 & 0.03 & 0.030 \\
\hline USA & 0.002 & -0.004 & 0.002 & 0.01 & 0.00 & 0.01 & 0.01 & 0.003 \\
\hline Chile & 0.000 & 0.010 & 0.020 & 0.02 & 0.02 & 0.02 & 0.03 & 0.030 \\
\hline Peru & -0.030 & -0.030 & -0.030 & -0.01 & -0.01 & -0.01 & -0.01 & -0.010 \\
\hline Vietnam & 0.810 & 0.490 & 0.490 & 1.51 & 1.85 & 1.51 & 1.96 & 2.340 \\
\hline Japan & -0.001 & 0.140 & 0.000 & -0.01 & 0.19 & -0.01 & -0.01 & 0.200 \\
\hline China & -0.003 & -0.020 & -0.020 & 0.28 & 0.30 & 0.28 & 0.28 & 0.300 \\
\hline Korea & 0.000 & -0.010 & 0.610 & -0.03 & -0.07 & -0.03 & 0.79 & 1.000 \\
\hline Canada & 0.010 & 0.000 & -0.010 & -0.02 & -0.03 & -0.02 & -0.02 & -0.030 \\
\hline Mexico & 0.010 & -0.010 & 0.010 & 0.02 & 0.01 & 0.02 & 0.02 & 0.010 \\
\hline Malaysia & 0.010 & 0.000 & -0.010 & -0.02 & -0.09 & -0.02 & -0.06 & -0.140 \\
\hline ASEAN & -0.004 & -0.010 & 0.000 & -0.03 & -0.06 & -0.03 & -0.03 & -0.080 \\
\hline Latin & -0.004 & -0.010 & -0.010 & -0.02 & -0.03 & -0.02 & -0.03 & -0.040 \\
\hline EU & -0.003 & -0.010 & -0.010 & -0.01 & -0.02 & -0.01 & -0.02 & -0.030 \\
\hline ROW & -0.002 & -0.010 & 0.000 & -0.02 & -0.02 & -0.02 & -0.02 & -0.030 \\
\hline \multicolumn{9}{|c|}{ Equivalent Variation (EV) } \\
\hline Australia & 344.000 & 1409.000 & 1099.000 & 792.00 & 1782.00 & 1956.00 & 1433.00 & 2216.000 \\
\hline New Zealand & 293.000 & 362.000 & 411.000 & 353.00 & 415.00 & 440.00 & 455.00 & 477.000 \\
\hline Singapore & 516.000 & 521.000 & 980.000 & 572.00 & 533.00 & 794.00 & 965.00 & 736.000 \\
\hline USA & 337.000 & 3788.000 & 399.000 & 2178.00 & 5056.00 & 2080.00 & 1173.00 & 2292.000 \\
\hline Chile & 23.000 & 136.000 & 71.000 & 70.00 & 171.00 & 159.00 & 97.00 & 174.000 \\
\hline Peru & -86.000 & -105.000 & -101.000 & -95.00 & -114.00 & -121.00 & -109.00 & -130.000 \\
\hline Vietnam & 1133.000 & 1442.000 & 1243.000 & 1212.00 & 1844.00 & 1617.00 & 1670.00 & 2038.000 \\
\hline Japan & -340.000 & 6637.000 & -3093.000 & -713.00 & 7931.00 & 12556.00 & -4067.00 & 13259.000 \\
\hline China & -509.000 & -1915.000 & 14358.000 & -1688.00 & -3342.00 & 11957.00 & 12847.00 & 10613.000 \\
\hline Korea & -92.000 & -582.000 & -1402.000 & 4495.00 & 3685.00 & -2792.00 & 7892.00 & 6309.000 \\
\hline Canada & -219.000 & -1110.000 & -1079.000 & -474.00 & -1344.00 & -1922.00 & -1294.00 & -2116.000 \\
\hline Mexico & -47.000 & -565.000 & -481.000 & -205.00 & -709.00 & -947.00 & -593.00 & -1055.000 \\
\hline Malaysia & -47.000 & -167.000 & -378.000 & -132.00 & -296.00 & -763.00 & -615.00 & -1041.000 \\
\hline ASEAN & -158.000 & -672.000 & -1156.000 & -421.00 & -1071.00 & -2363.00 & -1644.00 & -2981.000 \\
\hline Latin & -186.000 & -643.000 & -758.000 & -463.00 & -936.00 & -1325.00 & -1101.00 & -1698.000 \\
\hline EU & -874.000 & -3086.000 & -4816.000 & -1816.00 & -4270.00 & -8275.00 & -6080.00 & -9764.000 \\
\hline ROW & -236.000 & -1029.000 & -973.000 & -686.00 & -1709.00 & -2214.00 & -1816.00 & -3291.000 \\
\hline
\end{tabular}

Source: Model simulation

All seven scenarios show gains in economic welfare for most TPP countries, except for China and Korea. In the $\mathrm{TPP}+\mathrm{K}$ scenario, China would lose USD 1,687.83 million, while Korea would lose USD 1,402.45 million. For Peru, economic welfare decreased in all scenarios, particularly in the $\mathrm{TPP}+\mathrm{J}+\mathrm{C}+\mathrm{K}$ scenario, with a loss of USD 129.82 million. Among the losers, Vietnam's economic welfare would be the least impacted, with losses of USD 2,037.77 million $(\mathrm{TPP}+\mathrm{J}+\mathrm{C}+\mathrm{K})$, USD 1,874.01 million $(\mathrm{TPP}+\mathrm{J}+\mathrm{K})$, USD $1,670.04$ million $(\mathrm{TPP}+\mathrm{K}+\mathrm{C})$, USD 1,671.44 million $(\mathrm{TPP}+\mathrm{J}+\mathrm{C})$, USD $1,442.36$ million $(\mathrm{TPP}+\mathrm{J})$, USD $1,242.73$ million $(\mathrm{TPP}+\mathrm{K})$, USD 1,212.12 million $(\mathrm{TPP}+\mathrm{C})$ and USD 1,133.19 million (TPP), respectively. Non-member countries' loss in economic welfare can be attributed to the negative effects in terms of trade (Table 2).

In the following scenario, we focus on the effects of $\mathrm{TPP}+\mathrm{J}+\mathrm{C}+\mathrm{K}$ on production output for the different sectors. The percentage change is expressed in Table 4. Under this scenario, output increased in 4 out of 15 agriculture sectors within six countries, including livestock, meat products, fishing and processed foods in Australia, New Zealand, Singapore, the US, Chile and Peru. Meat products saw a total increase of more than $10 \%$, with $26.2 \%$ in Singapore, $21.9 \%$ in Chile, $17.5 \%$ in Australia and $10.3 \%$ in New Zealand. Moreover, the livestock sector saw increases of more than $10 \%$, with $13.8 \%$ in Chile and $11.7 \%$ in Australia. In addition, processed food had increases of more than $6 \%$, with $16.1 \%$ in Singapore, $7.5 \%$ in Australia and $6.7 \%$ in New Zealand. The largest increase was rice in Australia and the US, with 341.8 and $107.3 \%$, respectively.

However, output decreased for the textiles and apparel and light manufacturing sectors in seven countries including Australia, New Zealand, Singapore, the US, Chile, Peru and Japan. Textiles and apparel dropped $11.2 \%$ in Australia, $11.4 \%$ in New Zealand, $8.2 \%$ in Singapore, $5.6 \%$ in the US, $3.9 \%$ in Chile, $3.7 \%$ in Peru and $0.3 \%$ in Japan, while light manufacturing dropped $8.2 \%$ in Vietnam, $4.9 \%$ in New Zealand, $3.7 \%$ in Australia, $2.8 \%$ in Chile, $1.6 \%$ in Singapore, $1.0 \%$ in Peru and $0.7 \%$ in the US. 
Am. J. of Economics and Business Administration 4 (1): 40-46, 2012

Table 3: Production by sectors of TPP+ Japan, Korea and China (Unit: percent change)

\begin{tabular}{|c|c|c|c|c|c|c|c|c|c|c|c|c|c|c|c|c|c|}
\hline Regions/ Sector & Australia & New Zealand & Singapore & USA & Chile & Peru & Vietnam & Japan & China & Korea & Canada & Mexico & Malaysia & ASEAN & Latin & $\mathrm{EU}$ & ROW \\
\hline Rice & 341.81 & -2.21 & 2.90 & 107.25 & 0.86 & 0.22 & 2.50 & -37.91 & 13.12 & -79.02 & 22.76 & 24.85 & -0.02 & -0.09 & 3.22 & 3.24 & 0.26 \\
\hline Wheat & -13.00 & 3.98 & -10.31 & 1.26 & 1.36 & -7.03 & 29.84 & -62.24 & -1.77 & 41.52 & 0.69 & 3.51 & 0.25 & 6.59 & 2.75 & 0.66 & 0.86 \\
\hline Grains & 2.06 & -3.97 & -0.55 & 0.96 & -1.62 & 0.29 & -24.40 & -12.68 & 3.54 & 33.51 & -0.40 & 0.13 & -1.49 & 0.64 & -0.28 & -0.11 & -0.10 \\
\hline Vegetable & 0.41 & -2.07 & 0.00 & -0.88 & -1.62 & 1.02 & 19.66 & 0.14 & -0.09 & -13.03 & 2.22 & 1.11 & 1.66 & -0.44 & 0.62 & 0.2 & 0.01 \\
\hline Live & 11.72 & 7.28 & 2.47 & 4.35 & 13.87 & 0.2 & 0.30 & -21.38 & -1.74 & 6.98 & -1.99 & -0.28 & -0.13 & -0.94 & -0.67 & -0.26 & -0.05 \\
\hline Meat Product & 17.48 & 10.33 & 26.19 & 8.32 & 21.94 & 0.36 & -3.60 & -46.55 & -7.69 & 2.44 & -5.51 & -2.55 & -1.89 & -2.59 & -1.25 & -1.20 & 0.02 \\
\hline Fishing & 0.52 & 3.06 & 0.03 & 0.33 & 0.17 & 0.02 & -2.65 & -0.13 & 0.07 & 1.08 & 0.20 & -0.22 & -0.19 & -0.16 & 0.00 & -0.04 & -0.06 \\
\hline Process food & 7.52 & 6.69 & 16.06 & 0.80 & -0.41 & 0.6 & -23.57 & -0.29 & 0.70 & 10.31 & -0.66 & -0.47 & -1.64 & -0.41 & -0.29 & -0.21 & -0.35 \\
\hline Natural re: & -0.95 & -1.13 & -0.18 & -0.02 & -0.25 & 1.63 & -10.62 & -1.14 & -1.09 & -4.77 & 0.51 & 0.33 & 0.62 & 1.02 & 0.43 & 0.26 & 0.22 \\
\hline Textil & -11.19 & -11.38 & & -5.61 & -3.96 & -3.7 & 66.32 & -0.3 & 8.39 & 13.52 & & -6 & -9 . & -4.9 & -4.46 & -1.08 & -2.94 \\
\hline Light Manufacturing & -3.68 & -4.92 & -1.61 & -0.69 & -2.79 & -1.02 & -8.21 & 2.01 & 0.73 & 0.1 & -0.57 & -0.33 & -0.14 & 0.38 & 0.31 & -0.12 & 0.07 \\
\hline Heavy & -2.69 & -2.97 & 0.88 & 0.19 & -0.41 & 0.44 & -12.93 & 0. & -1.24 & -0.52 & 1.09 & 0.90 & -0.17 & 1.26 & 0.53 & 0.08 & -0.13 \\
\hline Utilities & 1.07 & 0.88 & 0.57 & 0.06 & 0.20 & 0.52 & 21.45 & 0. & 1.49 & 2.84 & -0.66 & -0.0 & -1.13 & -1.92 & -0.56 & -0.3 & -0.31 \\
\hline Trad & -0.01 & -0.20 & 0. & 0.02 & 0.16 & 0.3 & -3.83 & 0.0 & -0.54 & 0.76 & 0.15 & 0.2 & 0.89 & 0.38 & 0.19 & 0.15 & 0.16 \\
\hline Other Services & -0.15 & -0.03 & -0.93 & -0.04 & -0.07 & 0.09 & -8.61 & -0.02 & -0.51 & -0.33 & 0.11 & 0.09 & 0.50 & 0.09 & 0.09 & 0.02 & 0.10 \\
\hline
\end{tabular}

Source: Model Simulation

Table 4: Export by sectors of TPP+ Japan, Korea and China (Unit: Percent change)

\begin{tabular}{|c|c|c|c|c|c|c|c|c|c|c|c|c|c|c|c|c|c|}
\hline Regions/ Sector & Australia & New Zealand & Singapore & USA & Chile & Peru & Vietnam & Japan & China & Korea & Canada & Mexico & Malaysia & ASEAN & Latin & EU_25 & ROW \\
\hline Rice & 2991.79 & -3.62 & 4.38 & 388.54 & -4.14 & 26.521 & 1059.64 & 214.29 & 7056.59 & 18881.62 & 50.30 & 1.91 & 26.50 & 23.06 & 38.87 & 7.19 & 15.44 \\
\hline Wheat & -12.03 & -22.47 & -11.37 & 3.32 & -10.42 & 40.88 & 30.55 & 105.10 & 23.36 & 100.13 & -0.30 & 3.15 & -0.06 & 7.77 & 2.62 & 1.66 & 4.31 \\
\hline Grains & 5.63 & -11.39 & -0.31 & 6.10 & -5.05 & 5.10 & -28.39 & 26.93 & 14.05 & 212.17 & -1.89 & 0.09 & -15.30 & -0.41 & -2.25 & -0.92 & -0.28 \\
\hline Vegetable & -3.45 & -3.12 & 0.06 & -1.92 & -0.20 & 3.51 & 144.89 & 53.99 & -3.89 & 166.58 & 2.05 & 2.62 & 3.63 & -6.75 & 1.16 & -0.13 & -0.45 \\
\hline Livestock & 26.60 & 9.54 & 0.68 & 1.36 & -5.21 & 3.58 & -20.48 & 18.15 & -4.66 & 115.59 & 3.46 & 5.59 & 1.01 & 1.67 & 0.81 & -0.63 & -0.25 \\
\hline Meat Produ & 47.49 & 19.92 & 119.04 & 180.85 & 97.15 & 9.15 & -51.69 & 21.00 & -39.10 & $261.57-$ & -20.96 & -65.23 & -16.11 & -38.42 & -6.38 & -5.04 & -2.68 \\
\hline Fishing & 3.11 & -4.51 & 0.84 & 2.93 & 2.83 & 4.87 & 17.63 & 14.13 & 8.77 & 7.13 & 0.48 & 1.16 & 0.66 & 0.18 & 0.79 & -0.64 & -0.64 \\
\hline Process foo & 40.20 & 17.16 & 26.09 & 12.06 & -2.31 & 4.14 & -18.67 & 51.94 & 24.23 & 96.85 & -3.46 & -0.97 & -3.54 & -3.71 & -2.05 & -1.55 & -3.13 \\
\hline Natur & & & & & & 2.89 & & & & 14.85 & 0.26 & & & & & 0.28 & 0.14 \\
\hline Textiles & 30.33 & -11.35 & -9.47 & 0.37 & -1.32 & -6.29 & 117.23 & 47.99 & 23.94 & $33.05-$ & -16.99 & -16.55 & -11.65 & -9.88 & -14.59 & -3.74 & -6.57 \\
\hline Light Ma & -2.79 & -6.79 & -2.32 & 0.02 & -3.54 & 5.21 & 5.41 & 10.25 & 11.56 & 4.23 & -2.16 & -1.66 & -1.49 & -0.81 & -0.76 & -0.89 & -1.06 \\
\hline Heavy Manufacturing & -1.09 & -3.32 & 1.10 & 2.52 & 0.59 & 6.35 & -16.40 & 4.25 & 3.88 & 4.45 & 0.59 & 1.53 & -1.21 & 0.14 & 0.23 & -0.44 & -0.95 \\
\hline Utilities & -4.09 & -4.05 & -3.09 & -0.72 & -1.02 & 4.72 & -30.15 & -4.92 & -4.31 & -7.39 & 2.08 & 1.66 & 1.55 & 2.97 & 0.79 & 0.10 & 0.19 \\
\hline Trade & -3.09 & -1.74 & 0.55 & 0.55 & 1.25 & 3.95 & -5.72 & 0.64 & -2.53 & 1.29 & 2.51 & 2.45 & 2.45 & 3.42 & 2.06 & 1.34 & 1.51 \\
\hline Other Services & -4.02 & -3.48 & -2.74 & -0.48 & -1.15 & 3.55 & -30.07 & -3.37 & -5.20 & -7.59 & 2.11 & 2.63 & 1.90 & 3.76 & 1.81 & 0.28 & 0.73 \\
\hline
\end{tabular}

Source: Model simulation

As the result showed that trade creation's TPP agreement are much more positive in six countries; Australia, New Zealand, Singapore, USA, Chile and Peru; in terms of agriculture sectors as explained above, whereas Korea and China had positive output only on light manufacture sector but the percent change less than $1 \%$ increase except Japan increased by $2.0 \%$ (Table 3).

In general, the magnitude of export variation is lower than for imports. This is a very interesting result because of its trade expansion effects on the production sectors in TPP agreement, focus on the trade creation join the TPP (Table 4).

The biggest export gain is rice sector and this exports increase to all eight countries of ten. In fact, increased exports of rice $18881.6 \%$ for Korea, $7056.5 \%$ for China, 29991.7\% for Australia, $1059.6 \%$ for Vietnam, 388.5\% for US, $214.3 \%$ for Japan, $26.5 \%$ for Peru and $4.38 \%$ for Singapore. The other significant export increases were meat product and food process in Australia, New Zealand, Singapore and US, it accounts more than $10 \%$ increase.

\section{DISCUSSION}

Trans-Pacific Strategic Economic Partnership Agreement or TPP is a multilateral free trade agreement that strategically significant for the membership, the multilateral agreement reflect a consolidation of preexisting economic ties.

In this study, GTAP or CGE model is employed because the model provides a framework for assessing the effects of policy and structural changes on resource allocation by clarifying "who gains and who loese." CGE or GTAP models of trade allow researchers to provide a quantitative estimate of the potential economic consequences of different trade liberalization scenarios. This includes the impact on welfare, trade flows, prices, consumption and production.

An interesting observation is that under the TPP with Japan, Korea and China, Vietnam records the highest growth rate in real GDP and exports. The percent change in real export volume was 29.1 and $2.3 \%$ for real GDP. Moreover, the individual member countries were gains benefit both real GDP and welfare but the percent change of real GDP increase less than $1 \%$ while welfare increased much. This is in line with. Pertri el al. (2011) that Other Asian who are not TPP member, do not directly benefit at this early stage since they already have agreement with China, Japan and Korea. They do achieve new benefits in a second step, when the EAFTA create region-wide rules of origin and induces greater utilization of perferential access, especailly China, Japan and Korea are major beneficiaries. It confirms that TPP with Japan, Korea and China has largest gains for the member countries. 
However, the trade liberalization provides a significant negative effect on economies of non-member countries.

\section{CONCLUSION}

Limitation of study undertakes policy simulation using the GTAP model framework and database to anticipate the consequence of the TPP agreement with Japan, Korea and China. The data aggregation based on the 2004 GTAP database, distinguishes 15 sectors and 17 regions. The results highlight the importance for countries considering the implications of the agreement they are currently multilateral liberalization under TPP agreement compare with trade creation when Japan, Korea and China participate.

The major conclusion is that expansion member countries among TPP countries with East Asia countries including Japan, South-Korea and China, last case, would benefit from the FTA among member countries, gain much more from the real GDP and welfare than the TPP agreement, especially Vietnam, Korea gains more than $1 \%$ in real GDP while Peru fell both real GDP and welfare. However, the projection suggests that the TPP would have negative effects for all non-member economies except for Mexico in all cases and Malaysia in case of the TPP.

However, Rice production significantly increased in nine countries except Japan, Korea and New Zealand, while for other agriculture products the effects were different for each country. For example, production of grains, livestock, meat products, fishing, processed food and natural resource significantly decreased in Japan, while production of vegetables and fruit, livestock, meat production and natural resources decreased in China. While Korea decreased production of vegetables and natural resources.

In contrast with the industrial sector, which impacted by a decrease in production level, except, light manufacture sector increased in three countries, Japan, Korea and China but the percent change increase less. The biggest export gain is rice sector and this exports increase to all eight countries of ten.

Given these results from the GATP model simulation, it is clear that TPP would benefit both economies and welfare with the eliminate tariff rate.

There are some limitations in these projects due to the GTAP model itself and other factors. The GTAP model is a comparative static model, thus it is hard to capture some dynamic effects of trade liberalization and therefore the simulation and project in this study may not reflect the true outcome.

\section{REFERENCES}

Akira, T., 2004. The effects of the TPP on agricultural productions in Japan and China: A Computer Simulation Analysis by using GTAP model (in Japanese).

APC, 2009. Bilateral and Regional Trade Agreements: Productivity Commission Draft Research Report. 1st Edn., Productivity Commission, Canberra City, A.C.T., ISBN-10: 9781740373296, pp: 27.

APEC, 2009. Further Analytical Study on the Likely Economic Impact of an FTAAP. 1st Edn., APEC, pp: 30.

Bin, Z., 2011. The TPP enlargement and US intentions. China Institute of International Studies.

Broadbent, M., M. Hiebert and L. Ross, 2012. The significance of the trans-pacific partnership negotiations. CSIS.

DeRose, D.A., 1995. Regional Trading Arrangements among Developing Countries: The ASEAN Example. 1st Edn., Research Report 103, International Food Policy Research Institute, Washington, D.C., ISBN-10: 0896291065, pp: 129.

Dimarana, B. and R. McDougall, 2002. Global trade assistance and production. Center for Global Trade Analysis, Purdue University.

Dixit, A., 1975. Welfare effect of tax and price changes. J. Public Econ., 4: 103-123. DOI: 10.1016/00472727(75)90014-6

Fergusson, I.F. and B. Vaughn, 2011. The trans-pacific partnership agreement. CRS.

Hakim, B.H. and P.N. Osakwe, 2006. Global trade models and economic policy analyses: Relevance, risks and repercussions for Africa. Munich University Library, Germany.

Hanslow, K.J., 2000. A general welfare decomposition for CGE models. Purdue University Press.

Herreros, S., 2011. The Trans-Pacific Strategic Economic Partnership Agreement: A Latin American Perspective. 1st Edn., ECLAC, Santiago, Chile, ISBN: 9210545613, pp: 41.

Hertel, T.W., 1999. Global Trade Analysis: Modeling and Applications. 1st Edn., Cambridge University Press, Cambridge, ISBN: 0521643740, pp: 403.

Innwon, P., P. Soonchan and K. Sangkyom, 2010. A free trade area of the Asia Pacific (FTAAP): Is it desirable? Munich University Library in Germany.

Kuriyama, C., 2011. The mutual usefulness between APEC and TPP. APEC Policy Support Unit.

Lee, H. and D.A. Sumner, 2011. South Korea-U.S. free trade agreement will lower export barriers for California products. California Agric., 65: 66-72. 
Narayanan, G.B. and T.L. Walmsley, 2008. Global trade, assistance and production: The GTAP 7 data base. Center for Global Trade Analysis, Purdue University.

Person, K. and M. Horridge, 2003. Hands-on Computing with RunGTAP and WinGEM to Introduce GTAP and GEMPACK. Global Trade Analysis Project.

Pertri, P.A., M.G. Plummer and F. Zhai, 2011. The trans-pacific partnership and Asia-pacific integration: A quantitative assessment. Honolulu: East-West Center.
Todsadee, A., H. Kameyama and P. Lutes, 2012. The implications of trade liberalization on TPP countries' livestock product sector. Technical Bulletin of Faculty of Agriculture, Kagawa Univeristy.

USDMNZ, 2012. Headway at negotiating round in melbourne keeps Trans-Pacific Partnership (TPP) on track. United States Diplomatic Mission to New Zealand.

USJBC, 2011. Japan's successful participation in the Trans-Pacific Partnership (TPP) agreement. The US-Japan Business Council. 